Western University

Scholarship@Western

Aboriginal Policy Research Consortium International (APRCi)

$2-2012$

\title{
Effect of dialect on identification and severity of speech impairment in Indigenous Australian children
}

Bethany J. Toohill

Charles Sturt University

Sharynne McLeod

Charles Sturt University

Jane McCormack

Charles Sturt University

Follow this and additional works at: https://ir.lib.uwo.ca/aprci

Part of the Anthropological Linguistics and Sociolinguistics Commons

Citation of this paper:

Toohill, Bethany J.; McLeod, Sharynne; and McCormack, Jane, "Effect of dialect on identification and severity of speech impairment in Indigenous Australian children" (2012). Aboriginal Policy Research Consortium International (APRCi). 402.

https://ir.lib.uwo.ca/aprci/402 


\title{
Effect of dialect on identification and severity of speech impairment in Indigenous Australian children
}

\author{
BETHANY J. TOOHILL ${ }^{1}$, SHARYNNE MCLEOD ${ }^{2}, \&$ JANE MCCORMACK ${ }^{3}$ \\ ${ }^{1}$ School of Community Health, Charles Sturt University, Bathurst, Australia, ${ }^{2}$ Research Institute of \\ Professional Practice and Learning, Charles Sturt University, Bathurst, Australia, ${ }^{3}$ School of Teacher \\ Education and School of Community Health, Charles Sturt University, Bathurst, Australia
}

(Received 18 March 2010; Accepted 31 May 2011)

\begin{abstract}
This study investigated the effect of dialectal difference on identification and rating of severity of speech impairment in children from Indigenous Australian backgrounds. The speech of 15 Indigenous Australian children identified by their parents/caregivers and teachers as having 'difficulty talking and making speech sounds' was assessed using the Diagnostic Evaluation of Articulation and Phonology. Fourteen children were identified with speech impairment on the Diagnostic Evaluation of Articulation and Phonology using Standard Australian English (AusE) as the target pronunciation; whereas 13 were identified using Australian Aboriginal English (AAE) as the target. There was a statistically significant decrease in seven children's severity classification and a statistically significant increase in all children's percentage of consonants, vowels and phonemes correct when comparing AAE with AusE. Features of AAE used by the children included $/ \mathrm{h} /$ insertion and deletion, primary stress on the first syllable and diphthongs alternating with short clear vowels. It is important that speech-language pathologists consider children's dialect as one component of culturally and linguistically appropriate services.
\end{abstract}

Keywords: speech impairment, speech sound disorder, children, Indigenous Australians, Aboriginal English, dialect

\section{Introduction}

Within Western societies, dependent largely on expert and effective communication skills, childhood speech impairment can be detrimental to an individual's future success (Ruben, 2000). The majority of children referred to speech-language pathologists (SLPs) for assessment have a speech impairment (also called speech sound disorder; Broomfield \& Dodd, 2004; McLeod \& Baker, 2004; Mullen \& Schooling, 2010). Future outcomes for children with untreated speech impairment are not like those of typically developing children. Children with speech and language difficulties in their preschool years are at greater risk of reading, language and spelling impairment in later life (Lewis, Freebairn, \& Taylor, 2000). There is also greater risk of future academic, social and occupational concerns (Felsenfeld, Broen, \& McGue, 1994;

Correspondence: Sharynne McLeod, Research Institute of Professional Practice and Learning, Charles Sturt University, Panorama Avenue, Bathurst, NSW 2795, Australia. Tel: +61-2-63384463. Fax: +61-2-63384417. E-mail: smcleod@csu.edu.au

ISSN 0269-9206 print/ISSN 1464-5076 online (C) 2012 Informa UK Ltd.

DOI: $10.3109 / 02699206.2011 .595523$ 
Harrison, McLeod, Berthelsen, \& Walker, 2009; McCormack, McLeod, McAllister, \& Harrison, 2009). For Indigenous Australian children the associated risk of future concerns may be even greater (McTurk, Nutton, Lea, Robinson, \& Carapetis, 2008).

Speech-language pathology practice has traditionally used an impairment framework which focuses on a client's difficulties to guide assessment and intervention decisions (Duchan, 2001). Within this framework, SLPs administer assessments designed to determine if the child is functioning within or below the typical range, through comparison with population standards (Duchan, 2001). This black and white distinction stems from a medical model, which posits that deficits (such as speech impairment) are within the child and further suggests that intervention can focus on 'objective, separable and controllable parts of communication' (Duchan, 2001: 41). However, modes of clinical practice are changing to encompass a social framework (Byng, 2001). Within a social framework, SLPs investigate beyond the child's difficulties to consider holistically the factors, both personal and environmental, that contribute to, and impact on, a child's life (Duchan, 2001). The International Classification of Functioning, Disability and Health-Children and Youth version (WHO, 2007) is a framework that incorporates information about the child's body structure, functioning, participation, environmental and personal factors (McLeod \& Threats, 2008). Consideration of each of these factors is especially important when working with children from culturally and linguistically diverse (CALD) backgrounds, such as Indigenous children, since social factors, including dialect, community and the notion of typical, may differ from those of the SLP (Crago, 1992; Ball \& Bernhardt, 2008).

Across the world, many children communicate within CALD contexts. However, most Western research investigating speech impairment has focused chiefly on Caucasian, middle class, urban, English-speaking children who speak the standard variety of English in their specific geographical region (Bernhardt, Ball, \& Deby, 2007) and exclude multilingual and multidialectal children (e.g. Beitchman, Nair, Clegg, \& Patel, 1986; Tomblin, Records, Buckwalter, Zhang, Smith, \& O’Brien, 1997; Shriberg, Tomblin, \& McSweeny, 1999; Raitano, Pennington, Tunick, Boada, \& Shriberg, 2004; Archibald \& Gathercole, 2006; Rvachew, 2007; Sices, Taylor, Freebairn, Hansen, \& Lewis, 2007; McGrath, Hutaff-Lee, Scott, Boada, Shriberg, \& Pennington, 2008). Subsequently, the results and recommendations presented within the literature may not clearly reflect or assist culturally diverse groups.

\section{Dialectal difference}

SLPs need to be able to distinguish between dialectal speech differences and speech impairment in order to identify appropriate clients for intervention (McGregor, Williams, Hearst, \& Johnson, 1997; Bernhardt et al., 2007; Ball \& Bernhardt, 2008) and to select appropriate targets for their clients (Goldstein \& Iglesias, 2001). Failure to consider dialectal difference can result in misidentification through over-identification of speech errors, or conversely through underidentification, where dialectal difference is held accountable for all errors (McGregor et al., 1997; Goldstein \& Iglesias, 2001; Stockman, 2010). Additionally, failure to consider dialectal difference may result in specific phonological error patterns being targeted unnecessarily in therapy (Goldstein \& Iglesias, 2001).

Research investigating the impact of dialectal difference on identification and severity of speech impairment classification has been occurring for the past few decades with child speakers of African American English (e.g. Cole \& Taylor, 1990; Washington \& Craig, 1992; McGregor et al., 1997) and Puerto Rican Spanish (Goldstein \& Iglesias, 2001). All studies reported increases in children's scores on speech assessments when dialect was 
considered. Furthermore, Cole and Taylor (1990) reported changes in diagnosis (misdiagnosis of half the children when dialect was not considered), Washington and Craig (1992) reported a change in severity classification for three of eight children diagnosed with speech impairment (from severe to moderate) and Goldstein and Iglesias (2001) found changes in diagnosis and severity classification of children when dialect was taken into account.

In order to distinguish dialectal difference from impairment, and to prevent misidentification of communication disorders, SLPs need to consider phonological features, alongside social, cultural and behavioural differences (McGregor et al., 1997; Williams, 2000). McGregor and colleagues (1997) distinguished between true speech errors (impairment) and dialectal differences in African American children through implementation of a contrastive analysis. A contrastive analysis compares a child's speech production to adult targets from both the standard dialect and their home dialect to differentiate true speech errors from dialectal differences. Contrastive analyses provide a method by which SLPs can appropriately analyse and interpret the speech and language assessment data of children from CALD backgrounds more appropriately, in the absence of normative data and standardised tests for these non-standard populations.

\section{Indigenous Australians}

Indigenous Australians make up $\sim 2.5 \%$ of the Australian population, of which $38 \%$ are children aged less than 15 years (Australian Bureau of Statistics (ABS), 2006). Over 55,000 people $(0.3 \%$ of the Australian population) speak an Australian Indigenous language at home. Within Australia, many of the Indigenous languages and language variations used prior to colonisation (estimated at 250) have been lost (Victorian Aboriginal Corporation for Languages (VACL), 2010). Currently, less than 20 Indigenous languages are spoken across all generations and approximately 145 languages are spoken to some degree (Obata \& Lee, 2010). The continued existence of many surviving Indigenous languages is severely endangered (Obata \& Lee, 2010; VACL, 2010). Yet, the Australian Aboriginal heritage is rich and Indigenous communities are endeavouring to revive their languages (VACL, 2010), with language revitalisation programs seeing increases in the number of speakers using specific Indigenous languages (Obata \& Lee, 2010). At present, 12\% of the Indigenous Australian population speaks an Indigenous language at home (ABS, 2006). However, the majority $(83 \%)$ speak a form of English only (ABS, 2006), which may include a variation of Australian English, termed Australian Aboriginal English (AAE).

AAE is characterised by the use of English words with Aboriginal meanings, as well as differences in pronunciation, grammar and syntax (Sharpe, 1977; Kaldor \& Malcolm, 1979, 1982, 1991; Eagleson, 1982; Williams, 2000; Butcher, 2008). AAE differs phonologically, syntactically, semantically and pragmatically from standard Australian English (AusE) (Williams, 2000). The present study is primarily concerned with the differences in phonology between the two dialects. Appendix 1 lists the phonological features of AAE identified from previous research studies. These include 'alternation' (free variation) of interdental fricatives (/// and $/ \theta /$ ) with labio-dental fricatives $(/ \mathrm{v} /$ and $/ \mathrm{f} /$ ), initial $/ \mathrm{h} /$ insertion or deletion and 'alternation' (free variation) of voiced and voiceless plosives (Kaldor \& Malcolm, 1991: 7; Williams, 2000: 70).

Like children from African American backgrounds in the United States (Craig \& Washington, 2000), children from Indigenous backgrounds in Australia may be misidentified with communication impairments due to the lack of culturally appropriate tools. To date no one has investigated the effect of dialectal difference on the identification of speech impairment in Indigenous Australian children. 
In recent decades, SLPs have been encouraged to consider and apply sociolinguistic knowledge (such as dialectal differences and the impact of cultural settings on communication) in their clinical practice with clients from CALD backgrounds (Wolfram, 1993). In Australia, Gould (2008) has suggested eight modifications to the speech and language assessments of Indigenous Australian children. These considerations included appreciating the importance of context upon communication, utilising play-based and purposeful assessment tasks, following Indigenous ways of communicating, eliciting the child's home language, valuing the language culture and the child, being sensitive and specific and providing comparative information. The present study was designed to examine one of Gould's recommended modifications (square brackets added): 'Communication assessment tasks need to be sensitive and specific enough (provide sufficient and comprehensive data) to enable the diagnosis of language [and/or speech] difference vs. language [and/or speech] disorder and to provide for the analysis of severity of difficulty (including mild degrees of difficulty or difficulties in a few areas only)' (Gould, 2008: 648).

\section{Aims of the Current Research}

The specific question posed in this research was what is the effect of dialectal difference on the identification and the rating of severity of speech impairment in Indigenous Australian preschool children?

\section{Method}

Participants

Participants were 15 children ( 8 males and 7 females) aged $3 ; 11-5 ; 0$ years (mean $=4 ; 3, \mathrm{SD}=$ $0 ; 3$ ) and identified as Indigenous Australians by their parents/caregivers and early childhood teachers. The sample was recruited from two states of Australia (Victoria and New South Wales). Geographical locations included metropolitan areas, major regional and small regional areas.

All children were identified by their parents/caregivers or teachers with concerns about their speech; however, two children were also identified with concerns about expressive language and fluency, one with concerns about expressive language and one with concerns about voice and receptive language. All children spoke English as their primary language. Parents/caregivers and/or teachers indicated that the children did not have a developmental delay, structural abnormality (e.g. cleft lip/palate) or another specific diagnosis (e.g. autism) that may have been associated with delayed speech development. However, all had a history of otitis media.

\section{Instruments}

The articulation and phonology subtests from the Diagnostic Evaluation of Articulation and Phonology (DEAP, Dodd, Hua, Crosbie, Holm, \& Ozanne, 2002) were administered to assess speech production. The DEAP is a standardised speech assessment, which includes normative data from British and Australian children. The phonology subtest from the DEAP was used to determine the presence and rating of severity of speech impairment. Percent consonants correct (PCC), percent vowels correct (PVC) and percent phonemes correct (PPC) were calculated, and each child's PPC was compared with standardised norms on the 
DEAP. The articulation subtest from the DEAP was used to consider variability of 14 repeated words. The DEAP oro-motor subtest (Dodd et al., 2002) was used to screen children's ability to perform motoric tasks. For all of the DEAP assessments, a standard score greater than 1 SD below the mean (e.g. less than a standard score of 7) was considered to indicate the presence of impairment.

Pure-tone audiometry was utilised to screen children's hearing, using protocols recommended by the American Speech-Language-Hearing Association (ASHA, 1985). The ASHA guidelines for identification audiometry state, 'Usually school environments are not too noisy for screening at frequencies above $1000 \mathrm{~Hz}$ [hertz], but sometimes ambient noise will interfere with screening at $1000 \mathrm{~Hz}$ and at lower frequencies. The $1000-4000 \mathrm{~Hz}$ range was selected for the ASHA guidelines because it is less vulnerable to invalidation by ambient noise and because most significant hearing loss will include failure in this range' (ASHA, 1985: 51). Therefore, due to the noisy preschool environments in which the assessments took place, the $500 \mathrm{~Hz}$ frequency measure was not used to identify hearing loss. Possible hearing loss was defined as failure to respond to at least one frequency $(1000,2000,4000 \mathrm{~Hz})$ in either ear at $20 \mathrm{~dB}$. Children identified with possible hearing loss were referred for further audiometric assessment. The results of follow-up assessments were unavailable for the current research.

\section{Procedure}

All children within the study were recruited through early childhood centres within two states of Australia. Parents/caregivers and teachers were given a questionnaire as part of a larger study of 1097 children (Sound Effects Study, McLeod, Harrison, \& McAllister, 2007-2009), and one of the questions asked 'Does your child have difficulty talking and making speech sounds?' (Glascoe, 2000). Children who were identified as having difficulty talking and making speech sounds (yes/a little) were invited to participate in a comprehensive speech and language assessment. Assessments of children took place within the children's early childhood centres. Children who were identified by their parents and teachers as Indigenous Australians were included in this study.

A qualified SLP performed all the assessments for each child. Assessments were audiorecorded with the assent of the children and consent of their adult guardians using a Sony MP3 digital recorder (ICD-UX80) (Sony, Tokyo, Japan) (further information is outlined in McLeod, Harrison, \& McAllister, 2007-2009). First, the DEAP articulation and phonology subtests were administered. A cueing hierarchy was employed (description, binary choice, imitation) if the child did not respond or incorrectly labelled the pictures. Throughout the assessments, if a child refused to complete the subtest, the SLP moved on to the next task. On completion of the DEAP articulation and phonology subtests, the SLP administered the other assessment tasks. During administration of the assessment tasks, the SLP transcribed the children's responses online. The SLP re-listened to the audio-recordings of the assessments within 24 hours of the session to check transcription.

\section{Reliability}

Transcription by consensus was the reliability procedure used for children's speech transcription data (Shriberg, Kwiatkowski, \& Hoffmann, 1984). Two judges transcribed all children's productions of words on the DEAP. The first judge was a qualified SLP (author 3) and the second judge was a final-year SLP student (author 1). The first judge transcribed all productions live, and the second judge transcribed $25 \%$ of children live and $75 \%$ of children from the 
audio tapes. When there was a discrepancy in the transcriptions, both transcribers listened to the recording and weighting was given to the online transcription, acknowledging that the recording may have been distorted and visual cues were absent.

\section{Ethical considerations}

Ethical approval for undertaking the research was gained from the Charles Sturt University Human Ethics Committee (2007/211) and the CSU School of Community Health Ethics in Human Research Committee (405/2008/11). Furthermore, the research adhered to the guidelines for working with Aboriginal and Torres Strait Islander groups as outlined by the National Health and Medical Research Council National Statement on Ethical Conduct in Human Research. Parents of child participants were provided with information about the study through the preschool which their child attended. Consent to participate was provided by the childcare director and parents/caregivers, and assent was provided by the children prior to commencement of the assessments. Indigenous families were provided with the opportunity to request the involvement of an Indigenous liaison worker to assist in any way concerning the project to ensure their rights were protected. The researchers ensured the privacy and confidentiality of all children involved within the study through assigning numerical codes to all data. The preschool and families were provided with written and verbal feedback following the assessments and were offered the opportunity of referral to their local Aboriginal health service or SLP community health service.

\section{Analysis}

All data from the DEAP phonology assessment were entered into the Profile of Phonology (PROPH+; Long, 2003) using the Australian English (AusE) dictionary setting. This computer software program performed comprehensive phonological analyses including calculation of PCC and PVC. The PPC was calculated through adding the number of phonemes produced correctly (consonants and vowels) and dividing by the total number of phonemes produced (consonants and vowels). Each child's demographic information and results from each of the tests administered, including their PCC, PVC and PPC information, were entered into the statistical software package Statistical Program for the Social Sciences (SPSS; version 16.0; PASW Statistics, 2008).

Contrastive analysis: Determining the effect of dialectal difference. The contrastive analysis comprised seven steps: (1) The children's responses on the DEAP were analysed by comparing their productions to the AusE target words. (2) A summary of all the phonological features associated with AAE was developed (see Appendix 1). (3) The children's speech transcription data from the DEAP phonology subtest were analysed to identify AAE features (see Appendix 2). (4) The children's responses on the DEAP were then re-entered into $\mathrm{PROPH}+$, with the target transcriptions modified to accept the AAE features (see Appendix 2). (5) PROPH+ phonological analyses from the AAE transcription data were completed for each child, including PCC and PVC. From the PCC and PVC scores the PPC scores were then calculated. (6) Every child's PCC, PVC and PPC from both AusE and AAE analyses were compared to determine if dialectal difference affects the identification or rating of severity of speech impairment. To identify the severity of involvement for PCC, the Shriberg, Kwiatkowski, Best, Hengst, and Terselic-Weber scale (1986) was used to determine the effect of dialectal difference on rating of severity. (7) The AAE PCC, PVC 
and PPC information for each child were entered into SPSS, and a paired samples $t$-test was used to determine whether the difference between AusE and AAE raw scores was significant.

\section{Results}

\section{Summary of speech, hearing and oro-motor status}

Overall 14 of the 15 children (93.3\%) were identified with speech impairment on the phonology subtest of the DEAP. The mean PPC for participants, based on AusE, was 65.75 (SD =15.04, range $=39.51-89.45)$. The PPC of 14 of the 15 participants equated to a standard score which placed them outside the typical range for their age (standard score between 7 and 13 considered within the typical range), and resulted in a classification of speech impairment, as recommended by the DEAP manual. The rating of severity of speech impairment ranged from mild (one child) to severe (seven children). Table I includes gender, age, PCC, PVC and PPC in both AusE and AAE for all children. It also includes co-occurring impairments.

Seven $(46.7 \%)$ children were identified with a possible hearing loss in either ear at any of the following three frequencies: 1000, 2000 and $4000 \mathrm{~Hz}$. Follow-up audiometrical testing in a sound-treated booth was recommended for confirmation of hearing loss. Had $25 \mathrm{~dB}$ been used as per the World Health Organisation (WHO, 2010) guidelines, the identification may have been different (WHO, 2010). Two (20.0\%) children ( $n=10$ with valid data) were identified with possible oro-motor impairment based on their performance on any one of the oro-motor tasks: diadochokinetic rate, isolated movements and sequenced movements.

Table I. Demographic and assessment data for the participants $(n=15)$.

\begin{tabular}{|c|c|c|c|c|c|c|c|c|c|c|c|}
\hline \multirow{2}{*}{$\begin{array}{l}\text { Child } \\
\text { number }\end{array}$} & \multirow{2}{*}{$\begin{array}{c}\text { Gender } \\
\text { (male/female) }\end{array}$} & \multirow[b]{2}{*}{ Age } & \multicolumn{3}{|c|}{ AusE } & \multicolumn{3}{|c|}{ AAE } & \multicolumn{3}{|c|}{ Impairment } \\
\hline & & & PPC & PCC & PVC & PPC & PCC & PVC & Speech $^{a}$ & Hearing $^{b}$ & Oro-motor ${ }^{c}$ \\
\hline 1 & M & $5 ; 0$ & 39.5 & 26.1 & 64.8 & 47.8 & 35.1 & 71.8 & 1 & $\star$ & 1 \\
\hline 2 & $M$ & $3 ; 11$ & 42.7 & 21.2 & 81.1 & 51.0 & 33.6 & 81.1 & 1 & $\star$ & $\star$ \\
\hline 3 & $\mathrm{~F}$ & $3 ; 11$ & 53.8 & 38.7 & 81.0 & 61.8 & 50.0 & 82.3 & 1 & 1 & $\star$ \\
\hline 4 & M & $4 ; 3$ & 56.0 & 34.8 & 93.6 & 59.8 & 40.4 & 93.6 & 1 & $\star$ & $\star$ \\
\hline 5 & $M$ & $4 ; 1$ & 57.5 & 42.1 & 84.8 & 67.6 & 56.9 & 86.1 & 1 & $\star$ & 1 \\
\hline 6 & $\mathrm{~F}$ & $4 ; 1$ & 59.4 & 50.4 & 75.6 & 67.3 & 60.6 & 79.2 & 1 & 1 & $\star$ \\
\hline 7 & $M$ & $4 ; 3$ & 60.2 & 40.6 & 94.9 & 67.6 & 51.5 & 96.1 & 1 & 1 & $\star$ \\
\hline 8 & $M$ & $4 ; 3$ & 62.3 & 48.6 & 87.8 & 71.6 & 60.0 & 93.2 & 1 & 1 & $\star$ \\
\hline 9 & $\mathrm{~F}$ & $4 ; 4$ & 70.4 & 63.1 & 83.6 & 74.1 & 68.2 & 84.7 & 1 & 1 & $\star$ \\
\hline 10 & $\mathrm{~F}$ & $4 ; 8$ & 72.2 & 62.5 & 89.5 & 79.8 & 72.2 & 93.3 & 1 & 1 & $\star$ \\
\hline 11 & $M$ & $4 ; 6$ & 78.4 & 69.1 & 94.8 & 86.5 & 80.4 & 97.4 & 1 & $\star$ & $\star$ \\
\hline 12 & $\mathrm{~F}$ & $4 ; 1$ & 78.5 & 72.1 & 89.9 & 83.3 & $79.4^{\star}$ & 89.9 & 1 & 1 & $\star$ \\
\hline 13 & $M$ & $4 ; 6$ & 79.0 & 72.1 & 91.1 & 86.5 & 80.4 & 97.4 & 1 & $\star$ & $\star$ \\
\hline 14 & $\mathrm{~F}$ & $4 ; 1$ & $86.7^{\star}$ & $82.0^{\star}$ & 94.9 & $89.9^{\star}$ & $87.1^{\star}$ & 94.9 & $\star$ & $\star$ & $\star$ \\
\hline 15 & $\mathrm{~F}$ & $4 ; 7$ & 89.4 & $86.3^{\star}$ & 94.9 & $94.5^{\star}$ & $92.8^{\star}$ & 97.4 & 1 & $\star$ & $\star$ \\
\hline
\end{tabular}

Notes: AusE, standard Australian English; AAE, Australian Aboriginal English; PPC, percent phonemes correct; PCC, percent consonants correct; PVC, percent vowels correct. $1=$ impairment, ${ }^{\star}=$ no impairment.

${ }^{a}$ Assessed using Diagnostic Evaluation of Articulation and Phonology (DEAP, Dodd et al., 2002); impairment was designated by a standard score of $<7$ as recommended by the DEAP manual.

${ }^{b}$ Screened using pure-tone audiometry.

${ }^{c}$ Assessed using DEAP oro-motor subtest (Dodd et al., 2002). 
Impact of dialectal difference on identification and rating of severity of speech impairment

Total phonemes. Analysis of the DEAP phonology subtest using AusE identified 14 children (93.3\%) with speech impairment from PPC scores. When the data were re-analysed using AAE features (see Appendix 1), 13 Indigenous children (86.7\%) were identified with speech impairment.

After the AusE analysis, the mean PPC was 65.67 ( $\mathrm{SD}=15.04$, range = 39.51-89.45). Following AAE analysis, the mean PPC increased to 72.61 (SD $=14.08$, range $=47.80$ 94.50). The PPC of all children increased. The difference between AusE PPC scores and AAE PPC scores is presented in Figure 1(a). The mean difference between AusE and AAE PPC scores for all the Indigenous children within the sample was $6.86 \%(\mathrm{SD}=2.18$, range $=$ 3.21-10.06). A paired samples $t$-test revealed the difference between AusE and AAE PPC scores for Indigenous Australian children was significantly different at $p<0.000$.

Consonants. Analysis of consonant production using AusE identified two children (\#14 and \#15) within normal limits (based on DEAP standard scores for PCC). This increased to three children (\#12, \#14 and \#15) following the AAE analysis (see Table I). The mean AusE PCC

(a)

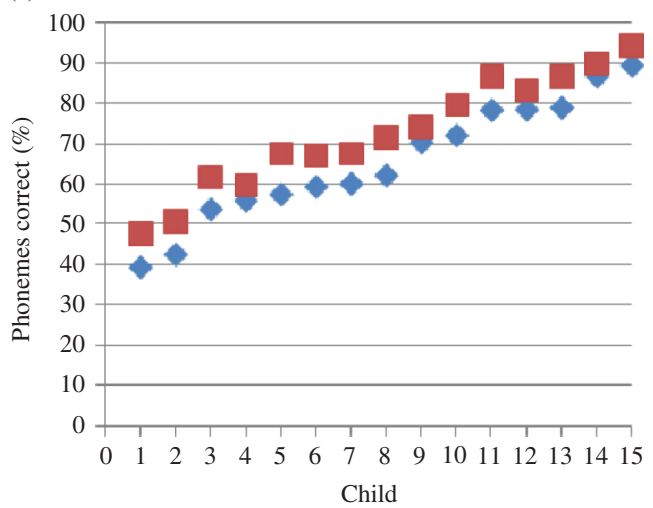

(b)

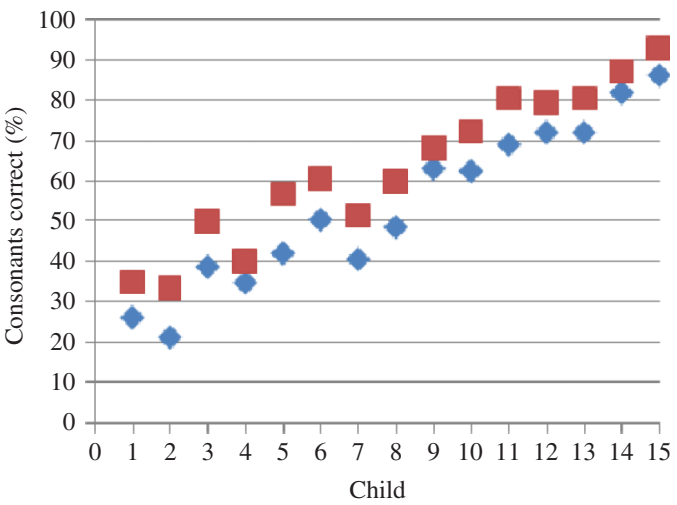

(c)

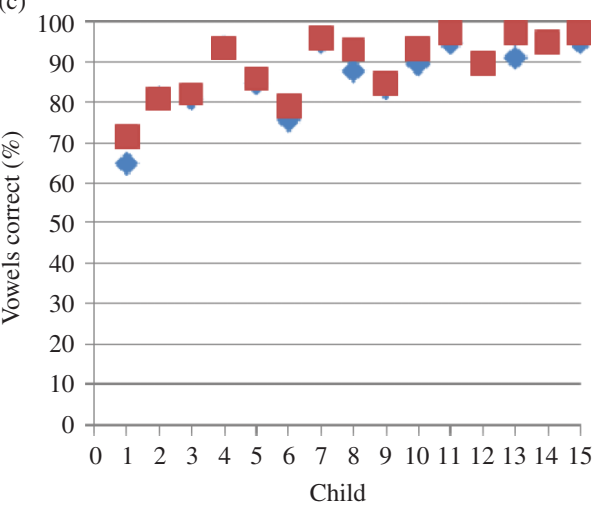

Figure 1. Difference between standard Australian English (diamonds) and Australian Aboriginal English (squares) for calculations of (a) percent phonemes correct (PPC), (b) percent consonants correct (PCC) and (c) percent vowels correct (PVC). 
was 53.98 ( $\mathrm{SD}=20.15$, range $=21.20-86.30)$. Following $\mathrm{AAE}$ analysis, the mean PCC increased to 63.24 ( $\mathrm{SD}=18.82$, range $=33.60-92.80$ ). PCC increased for all children following the AAE analysis (see Figure 1(b)). The mean difference between AusE and AAE PCC scores was $9.26 \%(\mathrm{SD}=2.90$, range $=5.1-14.8)$ that was statistically significant $(p<0.000)$.

Seven children were identified as having severe speech impairment (Shriberg et al., 1986), based on their PCC using the AusE analysis; three children were identified as having moderate-severe speech impairment; four as having mild-moderate speech impairment; and one as having mild speech impairment. Following AAE, three children were identified with severe speech impairment, five with moderate-severe speech impairment, five with mild-moderate and two with mild speech impairment. Thus, seven children were categorised as having less severe speech impairment when features of AAE were considered within their speech.

Vowels. Analysis of vowel production using AusE identified all children with speech impairment (based on DEAP standard scores for PVC); this remained unchanged following the AAE analysis. However, PVC (raw scores) increased for 11 children $(73.3 \%)$ following the AAE analysis (see Figure 1(c)). The AusE analysis of PVC revealed a mean score of $86.82(\mathrm{SD}=8.59$, range $=64.80-94.90)$. Following AAE analysis the mean PVC increased to 89.23 ( $\mathrm{SD}=7.93$, range $=71.80-97.40)$. The mean difference between AusE PVC and AAE PVC was $2.41 \%(\mathrm{SD}=2.35 \%$, range $=0-7)$ that was statistically significant $(p<0.001)$.

The severity classification decreased for four children (\#7, \#11, \#13 and \#15); however, their scores did not progress into the normal range. For the remaining 11 children, despite their increase in PVC, the overall rating of severity of their speech impairment was unchanged.

Aboriginal English features. The AAE features used by each child are presented in Table II. These included voicing plosives (45 occurrences and used by $73.3 \%$ of the sample), free variation of fricatives and stops (32 occurrences and used by $100 \%$ of sample) and substitution of [f] for target / $\theta /$ ( 23 occurrences and used by $80 \%$ of sample). The children used the following vowel features of AAE: alternating diphthongs with short clear vowels and insertion of schwa within a consonant cluster. It is acknowledged that some of the features of $\mathrm{AAE}$ are also developmental errors found within typically developing speakers of AusE. Others can also be identified as errors present within the speech of AusE children with speech impairment. The remaining features are only typical of AAE. Each feature has been labelled according to this distinction within Table II. Due to the developmental nature of certain features and others being typical errors found within speech impairment, it is unknown whether these features are present because the child is using AAE, or because they have speech delay/impairment.

\section{Discussion}

This research considered the effect of dialectal difference on identification and rating of severity of speech impairment in Indigenous Australian preschool children. Of the 15 participants, 14 were identified with speech impairment when their speech was compared to AusE norms. However, when characteristics of AAE were considered, 13 children were identified with speech impairment. That is, one child's speech no longer adhered to the criteria for 
Table II. Australian Aboriginal English (AAE) features used by children in study.

\begin{tabular}{|c|c|c|c|c|c|c|c|c|c|c|c|c|c|c|c|c|c|}
\hline \multirow{2}{*}{$\begin{array}{l}\text { Australian Aboriginal } \\
\text { English feature }\end{array}$} & \multirow{2}{*}{$\begin{array}{l}\text { Feature } \\
\text { type }\end{array}$} & \multicolumn{15}{|c|}{ Child number } & \multirow{2}{*}{$\begin{array}{l}\text { Percent children } \\
\text { using this feature }\end{array}$} \\
\hline & & 1 & 2 & 3 & 4 & 5 & 6 & 7 & 8 & 9 & 10 & 11 & 12 & 13 & 14 & 15 & \\
\hline Initial $/ \mathrm{h} /$ insertion & A & $\times$ & & $x$ & & & $\times$ & & $\times$ & & $\times$ & & $\times$ & & & & 40.0 \\
\hline Initial $/ \mathrm{h} /$ deletion & A & & & $\times$ & $\times$ & $\times$ & $\times$ & $\times$ & & & $\times$ & & $\times$ & & & & 46.7 \\
\hline $\begin{array}{l}\text { Primary stress on first } \\
\text { syllable }\end{array}$ & A & $x$ & & & & & $\times$ & $\times$ & $\times$ & $\times$ & $\times$ & & & $\times$ & & $\times$ & 53.3 \\
\hline $\begin{array}{l}\text { Diphthongs alternating with } \\
\text { short clear vowels }\end{array}$ & A & & & $\times$ & & & $\times$ & & & & $\times$ & $x$ & & $\times$ & & & 33.3 \\
\hline$/ \theta / \rightarrow[\mathrm{f}]$ & $\mathrm{D}$ & $x$ & & & & $\times$ & $\times$ & $\times$ & $\times$ & $\times$ & $\times$ & $\times$ & $\times$ & $\times$ & $\times$ & $x$ & 80.0 \\
\hline$/ \mathrm{d} / \rightarrow[\mathrm{v}]$ & $\mathrm{D}$ & & & & & & $\times$ & $\times$ & & & & $\times$ & & $x$ & $\times$ & $\times$ & 40.0 \\
\hline $\begin{array}{l}\text { Affricates and fricatives } \\
\text { alternating with palatals }\end{array}$ & $\mathrm{D}$ & & $\times$ & $\times$ & $\times$ & $\times$ & $\times$ & $\times$ & $\times$ & & & & & & & & 46.7 \\
\hline $\begin{array}{l}\text { Alternation of voiced and } \\
\text { voiceless plosives }\end{array}$ & SI & $\times$ & $\times$ & $\times$ & $\times$ & $\times$ & $\times$ & $\times$ & $\times$ & & & $\times$ & $\times$ & $\times$ & & & 73.3 \\
\hline $\begin{array}{l}\text { Fricatives alternating with } \\
\text { stops }\end{array}$ & SI & $\times$ & $\times$ & $\times$ & $\times$ & $\times$ & $\times$ & $\times$ & $\times$ & $\times$ & $\times$ & $\times$ & $\times$ & $\times$ & $\times$ & $\times$ & 100.0 \\
\hline Cluster reduction & SI & $\times$ & $x$ & $\times$ & $\times$ & $\times$ & $\times$ & $x$ & $\times$ & & $\times$ & $\times$ & $\times$ & $\times$ & & & 86.7 \\
\hline $\begin{array}{l}\text { Alternation of alveolar and } \\
\text { palatal fricatives }\end{array}$ & SI & $\times$ & & & $\times$ & $\times$ & & $x$ & & $\times$ & $\times$ & & $\times$ & & $x$ & $x$ & 60.0 \\
\hline$/ \mathrm{n} / \rightarrow[\mathrm{n}]$ & SI & $\times$ & $\times$ & $\times$ & & & & & & & $\times$ & & & & & & 26.7 \\
\hline $\begin{array}{r}\text { Insertion of /a/ } \\
\text { (epenthesis) }\end{array}$ & SI & & & & & & $\times$ & & & & & & & & & & 6.7 \\
\hline
\end{tabular}

Note: A, AAE feature only (shaded); D, AAE feature + a developmental error for 4- to 5-year-old children; SI, AAE feature + an error for children with speech impairment; $\times$, AAE feature used by child.

impairment. She continued to present with some speech errors; however, these were appropriate for her age.

Furthermore, following the contrastive analysis, PPC increased for all the children in this study. The mean improvement $(6.86 \%)$ in PPC was statistically significant. The main differences between AusE and AAE related to consonant production (see Appendix 1). The mean improvement $(9.26 \%)$ in PCC raw scores was also statistically significant, as was the mean improvement in PVC. Implementation of the contrastive analysis led to $93 \%$ (13 of the 15) of the Indigenous Australian children being categorised as having a less severe speech rating.

Results from this study (mean PCC increase of 9.26\%) are consistent with those of Goldstein and Iglesias (2001), who reported a 10.1\% increase in PCC when consideration was given to the home dialect of Spanish-speaking children. Furthermore, results are similar to both Goldstein and Iglesias (2001) and Washington and Craig (1992) who all reported a shift in severity category for some children when dialect was considered. In the present study, the speech impairment experienced by 7 of the 15 children was categorised as being less severe when features of AAE were considered within their speech.

\section{Dialectal difference versus true speech errors}

There were four features affecting speech production that were unique to AAE (and not typical phonological patterns for English-speaking children), including the insertion of $/ \mathrm{h} /$ in initial position, which was used by six children, and the deletion of $/ \mathrm{h} /$ in initial position, used by seven 
children. Primary stress on the first syllable was used by eight children and diphthongs alternating with short clear vowels were evident in the speech of five children. Only two children within the sample did not produce any of these four AAE-specific features. There were three AAE features used by the sample of 15 Indigenous children that are also considered developmental in AusE for 4- to 5-year-olds (Dodd et al., 2002). The substitution of [f] for $/ \theta /$ was used by 12 children and [v] was substituted for /ð/ by six children. Seven children alternated affricates and fricatives with palatals. Finally, there were six AAE features that are considered to be typical phonological patterns evident in children with speech impairment (Dodd et al., 2002). Eleven children voiced plosives, 15 alternated fricatives with stops, 12 reduced clusters, 9 alternated alveolar with palatal fricatives, 4 substituted $[\mathrm{n}]$ for $/ \mathrm{y} /$ and 1 child inserted $/ \mathrm{\partial} /$ within a consonant cluster.

McGregor et al., (1997: 52) recognised the difficulty of 'determining the developmental appropriateness of true errors' in African American English speakers, due to the lack of research regarding the acquisition of features in children learning two dialects. However, preliminary research in African American English-speaking children indicates that certain phonemes develop at different times to mainstream American English speakers (Pearson, Velleman, Bryant, \& Charko, 2009; Stockman, 2010). In this study, some of the AAE features were consistent with typical development or errors common to children with speech impairment. It is difficult to determine the developmental appropriateness of these features for Indigenous children, given that phoneme acquisition has not been fully investigated in this population. However, it is possible that order of phoneme acquisition is different for AAE and AusE (Gould, 2009).

While a contrastive analysis enables a comparison of speech development between children from CALD backgrounds and their peers from the majority culture, it does not provide for comparison within the minority culture (i.e. among children also learning multiple dialects). Thus, future research investigating typical acquisition of phonemes for children learning multiple dialects is required to ensure accurate identification of true speech errors and accurate diagnosis of communication impairment. However, a greater understanding of the language socialisation practices of these populations as well as the way in which impairments present is also required (Crago, 1992; Craig \& Washington, 2000). Crago (1992: 35) suggests SLPs require 'ethnographic documentation' of language socialisation practices in order to 'become culturally literate and knowledgeable' in their management of children with communication impairment who are not from the majority culture.

Recognising the wealth of knowledge to be gained from members of Indigenous Australian communities, and collaborating with them in future studies, could provide useful information about typical speech development in Indigenous Australian children and the language socialisation practices of their culture. Ball and Bernhardt (2008: 582) refer to this as 'decolonizing research methodology' or recognising that community members (rather than the SLPs or the researchers) are the experts on their culture and communication development within that culture. In this study, the concerns of parents/teachers within the Indigenous community were used to identify potential child participants, which is consistent with Ball and Bernhardt's recommendation.

Variability. Children's speech is variable both for typically developing children and children with speech impairment. For typical children, variability of word production decreases with age (Holm, Crosbie, \& Dodd, 2007; McLeod \& Hewett, 2008). For children from CALD backgrounds, dialectal density (or the degree of usage of dialectal features; Craig \& Washington, 2000) also appears to decrease with age (Goldstein \& Iglesias, 2001). It may 
be that changes in dialect usage are associated with children's increased exposure to the majority culture as they age rather than the 'somewhat restricted' interactional networks they have in the early childhood years (primarily family) (Roberts, 1997: 263).

This study did not focus on variability of word productions or overall frequency of dialect usage. However, the DEAP articulation and phonology subtests have 14 identical target words and children did produce some of these words differently. For example, one Indigenous child was observed to produce two variations of the word this /ðIs/: the AAE variation [dIs] and the AusE variation [ðIs]. It is unknown whether this variability was due to (1) differences between AusE and AAE (see Appendix 2); (2) typical development with the later developing sound /ð/ emerging within a child's speech; therefore, substitution of the earlier developing sound / $\mathrm{d} /$ was still occurring; (3) code switching between the two dialects; or alternatively, (4) pragmatic influences or cognitive-linguistic factors (Holm et al., 2007).

\section{Integrating the impairment and social frameworks in clinical practice}

The impairment framework of SLP practice supports the notion that deficits are within the child and intervention can target these objectively and separately (Duchan, 2001). Using this impairment framework, it is the role of the SLP to be the gatekeeper determining whether children have speech impairment and consequently whether they should receive services (Wolfram, 1993). Within health and education sectors in Western nations, the impairment framework is the status quo and is used for prioritising and funding decisions regarding services. Within this context, the majority of children in this study would be identified as requiring services.

Implementing the impairment framework alone is not enough, as it fails to take into account an individual's unique personal and environmental context. The social framework is 'life-centred' (Duchan, 2001: 38) and considers psychosocial factors (age, gender, temperament, personality, family background, culture) and the impact these may have on communication and the effectiveness of intervention. Within this study, one element of the social framework was implemented by considering the impact of dialectal difference. After considering dialectal difference, one child was no longer identified with speech impairment and the severity classification for seven children decreased. Thus, the importance of integrating both the impairment and social frameworks, and adopting a more holistic approach to clinical decision-making, was highlighted. McLeod suggests SLPs must regard their work as both gatekeepers and anthropologists; integrating both the impairment and social frameworks:

... instead of looking backward to the transcription textbooks of our professional training for acceptable pronunciations, SLPs should be listening as anthropologists to the speech of those within their local communities. (2003: 60)

Stockman (2010) suggests it is not enough for researchers to obtain information about the features of dialects and the impact of those features on identification of impairment, but it is also essential to educate SLPs about these differences so they can apply this knowledge in clinical practice. She questioned whether SLPs in America were adequately prepared to work with clients from African American backgrounds (in perceiving typical speech patterns that differ from clinician's own and in performing contrastive analyses). Similar questions could be raised about Australian SLPs' preparedness to work with children from Indigenous backgrounds. 
Knowledge enabling accurate identification of speech impairment in children from CALD backgrounds is only the first step in providing culturally appropriate SLP services. There is also a need for knowledge regarding how to implement intervention with minority groups 'in ways that resonate with the community and family communication and cultural patterns' (Ball \& Bernhardt, 2008: 583). For Indigenous Australian children, Gould (2008) suggests discussing parent concerns, determining what is impacting on overall intelligibility and targeting speech difficulties that are relevant to the dialect and speech characteristics of children should assist in the provision of culturally appropriate intervention.

\section{Limitations}

The present study had several limitations which should be addressed in future research. The parent questionnaire did not include additional questions regarding each Indigenous child's specific cultural and linguistic background, such as use of Indigenous languages, identification of AAE as a dialect and its use within the home. Further, this study analysed data from a small number of Indigenous children from different geographical contexts (metropolitan, small and large regional). Therefore, results cannot be generalised to all Indigenous Australian children.

Within this study, an assumption had to be made about AAE being standard across Australia, since there is no current data to discriminate between differing forms of AAE. Therefore, all AAE variations found within the literature to date were considered in the present research (Appendix 1). It is acknowledged that the numerous Indigenous languages found throughout Australia will not produce a uniform language or uniform AAE dialect throughout Australia.

Gould (2008) proposed eight modifications to consider when assessing Indigenous Australian children and this study employed one of these: using 'sufficient and comprehensive data to enable the diagnosis of language difference vs language disorder' (Gould, 2008: 648). This single modification was supported by McGregor et al. (1997: 53) who reported contrastive analyses to 'be helpful in distinguishing differences from disorders in nonstandard speakers'. Consideration of this one factor had an effect on the results obtained regarding identification and rating of severity of speech impairment. However, all suggested modifications were not implemented, such as including a conversational speech sample during the assessment. Therefore, the results may not highlight the extent of potential differences.

\section{Future directions for research}

Research regarding the acquisition of phonemes and language features in Indigenous Australian children learning both AusE and AAE is important to further investigate the impact of language and dialect on identification and severity ratings of impairment. Culturally appropriate research should include investigation of children's speech patterns and personal views regarding their communication, in addition, to identifying the concerns of each child's parents, teachers and SLPs.

\section{Conclusion}

Childhood speech impairment has lifelong implications and intervention is effective at managing these effects; therefore appropriate identification is essential. However, SLPs must consider the social contexts within which a child communicates. The findings from 
this study supported the implementation of modifications to the analysis of speech assessments for Indigenous Australian children as a first step in developing culturally appropriate practices for identifying and managing speech impairment in Indigenous Australian children. Future directions for research have also been identified to enhance our understanding of communication development and impairment for children from CALD backgrounds (including Indigenous Australian children). SLPs are advocates for those with communication difficulties. Thus, SLPs have 'an incumbent moral obligation' to 'acquire, apply, and disseminate reliable and valid perspectives about language variation throughout society' (Wolfram, 1993: 185). It is our responsibility to empower individuals, appreciate cultural and linguistic diversity and recognise that no accent, dialect or language should be privileged when considering children in context.

\section{Acknowledgements}

The authors thank the children, parents and their teachers for their involvement in this research and the following people for advice regarding this research: Terry Hawkins, Linda J. Harrison, Lindy McAllister, Cori Williams and Diane Jacobs.

Declaration of interest: This research was supported by the following sources: Australian Research Council Discovery Grant DP0773978 (McLeod and McCormack), Charles Sturt University Honours Scholarship (Toohill), the Australian Research Council Future Fellowship FT0990588 (McLeod) and the Charles Sturt University Research Institute for Professional Practice, Learning and Education (RIPPLE).

\section{Note}

1. It is acknowledged that the original use of the severity scale was based on connected speech.

\section{References}

American Speech-Language and Hearing Association (ASHA). (1985). Guidelines for identification audiometry. ASHA Leader, 27, 49-52.

Archibald, L. M. D., \& Gathercole, S. E. (2006). Prevalence of SLI in language resource units. Fournal of Research in Special Educational Needs, 6(1), 3-10.

Australian Bureau of Statistics (ABS). (2006). Population characteristics, Aboriginal and Torres Strait Islander Australians, 2006. Accessed 16 September 2008, from: http://www.abs.gov.au/AUSSTATS/abs@.nsf/ ProductsbyCatalogue/2B3D3A062FF56BC1CA256DCE007FBFFA?OpenDocument

Ball, J., \& Bernhardt, B. M. (2008). First nations English dialects in Canada: Implications for speech-language pathology. Clinical Linguistics and Phonetics, 22(8), 570-588.

Beitchman, J. H., Nair, R., Clegg, M., \& Patel, P. G. (1986). Prevalence of speech and language disorders in 5-yearold kindergarten children in the Ottawa-Carleton region. Fournal of Speech and Hearing Disorders, 51(2), 98-110.

Bernhardt, B., Ball, J., \& Deby, J. (2007). Cross-cultural interaction and children's speech acquisition. In S. McLeod (Ed.), The international guide to speech acquisition (pp. 101-106). Clifton Park, NY: Thomson Delmar Learning.

Broomfield, J., \& Dodd, B. (2004). The nature of referred subtypes of primary speech disability. Child Language Teaching and Therapy, 20(2), 135-151.

Butcher, A. (2008). Linguistic aspects of Australian Aboriginal English. Clinical Linguistics and Phonetics, 22(8), 625-642.

Byng, S. (2001). Integrating therapies. Advances in Speech-Language Pathology, 3(1), 67-71.

Cole, P., \& Taylor, O. (1990). Performance of working class African-American children on three tests of articulation. Language, Speech, and Hearing Services in Schools, 21, 171-176. 
Crago, M. B. (1992). Ethnography and language socialization: A cross-cultural perspective. Topics in Language Disorders, 12(3), 28-39.

Craig, H. K., \& Washington, J. A. (2000). An assessment battery for identifying language impairments in African American children. Language, Speech, and Hearing Services in Schools, 43, 366-379.

Dodd, B., Hua, Z., Crosbie, S., Holm, A., \& Ozanne, A. (2002). Diagnostic Evaluation of Articulation and Phonology. London: The Psychological Corporation.

Duchan, J. F. (2001). Impairment and social views of speech-language pathology: Clinical practices re-examined. Advances in Speech-Language Pathology, 3(1), 37-45.

Eagleson, R. D. (1982). Aboriginal English in an urban setting. In R. D. Eagleson, S. Kaldor, \& I. Malcolm (Eds.), English and the Aboriginal child (pp. 113-162). Canberra: Curriculum Development Centre.

Felsenfeld, S., Broen, P. A., \& McGue, M. (1994). A 28-year follow-up of adults with a history of moderate phonological disorder: Educational and occupational results. Fournal of Speech and Hearing Research, 37, 1341-1353.

Glascoe, F. P. (2000). Parents' Evaluation of Developmental Status: Authorized Australian version. Parkville, Victoria: Centre for Community Child Health.

Goldstein, B. A., \& Iglesias, A. (2001). The effect of dialect on phonological analysis: Evidence from Spanishspeaking children. American fournal of Speech-Language Pathology, 10(4), 394-406.

Gould, J. (2008). Non-standard assessment practices in the evaluation of communication in Australian Aboriginal children. Clinical Linguistics and Phonetics, 22(8), 643-657.

Gould, J. (2009). There is more to communication than tongue placement and 'show and tell': Discussing communication from a speech pathology perspective. Australian fournal of Linguistics, 29(1), 59-73.

Harrison, L. J., McLeod, S., Berthelsen, D., \& Walker, S. (2009). Literacy, numeracy and learning in school-aged children identified as having speech and language impairment in early childhood. International fournal of SpeechLanguage Pathology, 11(5), 392-403.

Holm, A., Crosbie, S., \& Dodd, B. (2007). Differentiating normal variability from inconsistency in children's speech: Normative data. International fournal of Language and Communication Disorders, 42(4), 467-486.

Kaldor, S., \& Malcolm, I. (1991). Aboriginal English: An overview. In S. Romaine (Ed.), Language in Australia (pp. 67-83). Cambridge: Cambridge University Press.

Kaldor, S., \& Malcolm, I. G. (1979). The language of the school and the language of the Western Australian Aboriginal school child: Implications for education. In R. M. Berndt \& C. H. Berndt (Eds.), Aborigines of the West: Their past and their present. Nedlands: University of Western Australia Press.

Kaldor, S., \& Malcolm, I. G. (1982). Aboriginal English in country and remote areas: A Western Australian perspective. In R. D. Eagleson, S. Kaldor, \& I. G. Malcolm (Eds.), English and the Aboriginal child. Canberra: Curriculum Development Centre.

Lewis, B. A., Freebairn, L. A., \& Taylor, H. G. (2000). Follow-up of children with early expressive phonology disorders. Fournal of Learning Disabilities, 33(5), 433-444.

Long, S. (2003). Computerized profiling. Accessed 29 September 2008, from: http://www.computerizedprofiling. org/cpinfo.html

McCormack, J., McLeod, S., McAllister, L., \& Harrison, L. J. (2009). A systematic review of the association between childhood speech impairment and participation across the lifespan. International fournal of Speech-Language Pathology, 11(2), 155-170.

McGrath, L. M., Hutaff-Lee, C., Scott, A., Boada, R., Shriberg, L. D., \& Pennington, B. F. (2008). Children with comorbid speech sound disorder and specific language impairment are at increased risk for attention-deficit/ hyperactivity disorder. Fournal of Abnormal Child Psychology, 36, 151-163.

McGregor, K. K., Williams, D., Hearst, S., \& Johnson, A. C. (1997). The use of contrastive analysis in distinguishing difference from disorder: A tutorial. American fournal of Speech-Language Pathology, 6(3), 45-56.

McLeod, S. (2003). Normal speech development: A framework for assessment and intervention. In C. Williams \& S. Leitao (Eds.), Speech Pathology Australia national conference (pp. 57-63). Melbourne: Speech Pathology Australia.

McLeod, S., \& Baker, E. (2004). Current clinical practice for children with speech impairment. In B. E. Murdoch, J. Goozee, B. M. Whelan, \& K. Docking (Eds.), Proceedings of the 26th world congress of the International Association of Logopedics and Phoniatrics. Brisbane: University of Queensland.

McLeod, S., Harrison, L. J., \& McAllister, L. (2007-2009). Children with speech impairment: A population study of prevalence, severity, impact and service provision. Australian Research Council Discovery Grant (DP0773978).

McLeod, S., \& Hewett, S. R. (2008). Variability in the production of words containing consonant clusters by typical 2- and 3-year-old children. Folia Phoniatrica et Logopaedica, 60, 163-172.

McLeod, S., \& Threats, T. T. (2008). The ICF-CY and children with communication disabilities. International fournal of Speech-Language Pathology, 10(1-2), 92-109. 
McTurk, N., Nutton, G., Lea, T., Robinson, G., \& Carapetis, J. (2008). The school readiness of Australian Indigenous children: A review of the liter ature. Darwin: Charles Darwin University.

Mullen, R., \& Schooling, T. (2010). The national outcomes measurement system for pediatric speech-language pathology. Language, Speech, and Hearing Services in Schools, 41, 44-60.

Obata, K., \& Lee, J. (2010). Feature article 3: Languages of Aboriginal and Torres Strait Islander peoples: A uniquely Australian heritage. In Australian Bureau of Statistics (Eds.), 1301.0 - Year Book Australia, 2009-10. Accessed 24 September 2010, from: http://www.abs.gov.au/AUSSTATS/abs@.nsf/Lookup/1301.0Feature+Article42009-10

PASW Statistics. (2008). Statistical program for the Social Sciences (SPSS) (Version 16.0). Chicago, IL: SPSS. Inc.

Pearson, B. Z., Velleman, S. L., Bryant, T. J., \& Charko, T. (2009). Phonological milestones for African American English-speaking children learning mainstream American English as a second dialect. Language, Speech, and Hearing Services in Schools, 40, 229-244.

Raitano, N. A., Pennington, B. F., Tunick, R. A., Boada, R., \& Shriberg, L. D. (2004). Pre-literacy skills of subgroups of children with speech sound disorders. Fournal of Child Psychology and Psychiatry, 45(4), 821-883.

Roberts, J. (1997). Hitting a moving target: Acquisition of sound change in progress by Philadelphia children. Language Variation and Change, 9, 249-266.

Ruben, R. J. (2000). Redefining the survival of the fittest: Communication disorders in the 21 st century. The Laryngoscope, 110 (2 part 1), 241-245.

Rvachew, S. (2007). Phonological processing and reading in children with speech sound disorders. American fournal of Speech-Language Pathology, 16, 260-270.

Sharpe, M. C. (1977). Alice Springs Aboriginal English. In E. Brumby \& E. Vaszolyi (Eds.), Language problems and Aboriginal education. Perth: Mt. Lawley College of Advanced Education.

Shriberg, L., Kwiatkowski, J., Best, S., Hengst, J., \& Terselic-Weber, B. (1986). Characteristics of children within phonological disorders of unknown origin. Fournal of Speech and Hearing Disorders, 51, 140-161.

Shriberg, L., Kwiatkowski, J., \& Hoffmann, K. (1984). A procedure for phonetic transcription by consensus. Fournal of Speech and Hearing Research, 27, 456-465.

Shriberg, L. D., Tomblin, J. B., \& McSweeny, J. L. (1999). Prevalence of speech delay in 6-year-old children and comorbidity with language impairment. Fournal of Speech, Language, and Hearing Research, 42(6), 1461-1481.

Sices, L., Taylor, H. G., Freebairn, L., Hansen, A., \& Lewis, B. (2007). Relationship between speech-sound disorders and early literacy skills in preschool-age children: Impact of comorbid language impairment. Fournal of Developmental and Behavioral Pediatrics, 28, 438-447.

Stockman, I. J. (2010). A review of developmental and applied language research on African American children: From a deficit to difference perspective on dialect differences. Language, Speech, and Hearing Services in Schools, 41 (1), 23-38.

Tomblin, J. B., Records, N. L., Buckwalter, P., Zhang, X., Smith, E., \& O’Brien, M. (1997). Prevalence of specific language impairment in kindergarten children. Fournal of Speech, Language, and Hearing Research, 40(6), $1245-1260$.

Victorian Aboriginal Corporation for Languages (VACL). (2010). About us. Accessed 25 February 2010, from: http://www.vaclang.org.au/

Washington, J., \& Craig, H. (1992). Articulation test performances of low-income African American preschoolers with communication impairments. Language, Speech, and Hearing Services in Schools, 23, 201-207.

Williams, C. (2000). Multiculturalism: Language in Aboriginal Australia: Aboriginal English. ACQuiring Knowledge in Speech, Language and Hearing, 2(2), 70-72.

Wolfram, W. (1993). A proactive role for speech-language pathologists in sociolinguistic education. Language, Speech, and Hearing Services in Schools, 24, 181-185.

World Health Organization. (2007). ICF: International classification of functioning, disability and health - children and youth version. Geneva: Author.

World Health Organization. (2010). Grades of hearing impairment. Geneva: World Health Organization. 


\section{Appendix 1: Features of Australian Aboriginal English (AAE) phonology}

\begin{tabular}{|c|c|c|c|c|c|c|}
\hline $\begin{array}{l}\text { Aboriginal English } \\
\text { phonological feature } \\
\text { (phonological } \\
\text { pattern) }\end{array}$ & Description & Example & Sample & Location & $\begin{array}{l}\text { Primary } \\
\text { source }\end{array}$ & $\begin{array}{l}\text { Secondary } \\
\text { source }\end{array}$ \\
\hline $\begin{array}{l}/ \mathrm{d} / \text { alternating with } \\
/ \mathrm{V} / \text { (fricative } \\
\text { simplification) }\end{array}$ & $\begin{array}{l}\text { Interdental fricatives } \\
\text { replaced by labio- } \\
\text { dental fricatives } \\
\text { (Williams, 2000) }\end{array}$ & with /wıð/ $\rightarrow$ [wIv] & $\begin{array}{l}\text { Children } \\
(10 ; 0- \\
17 ; 0) \text { and } \\
\text { adults }\end{array}$ & $\begin{array}{l}\text { Sydney } \\
\text { area }\end{array}$ & $\begin{array}{l}\text { Eagleson } \\
(1982)\end{array}$ & $\begin{array}{l}\text { Kaldor and } \\
\text { Malcolm } \\
(1991), \\
\text { Williams } \\
(2000)\end{array}$ \\
\hline $\begin{array}{l}/ \theta / \text { alternating with } \\
/ \mathrm{f} / \text { (fricative } \\
\text { simplification) }\end{array}$ & $\begin{array}{l}\text { Interdental fricatives } \\
\text { replaced by labio- } \\
\text { dental fricatives } \\
\text { (Williams, 2000) }\end{array}$ & $\begin{array}{l}\text { things } / \theta \mathrm{Inz} / \rightarrow \\
{[\mathrm{finz}]}\end{array}$ & $\begin{array}{l}\text { Children } \\
(10 ; 0- \\
17 ; 0) \text { and } \\
\text { adults }\end{array}$ & $\begin{array}{l}\text { Sydney } \\
\text { area }\end{array}$ & $\begin{array}{l}\text { Eagleson } \\
(1982)\end{array}$ & $\begin{array}{l}\text { Kaldor and } \\
\text { Malcolm } \\
(1991), \\
\text { Williams } \\
(2000)\end{array}$ \\
\hline $\begin{array}{l}/ \mathrm{y} / \text { substituted by } \\
{[\mathrm{n}] \text { (velar fronting) }}\end{array}$ & $\begin{array}{l}\text { Velar nasal replaced by } \\
\text { alveolar nasal (word } \\
\text { final) (Williams, 2000) }\end{array}$ & $\begin{array}{l}\text { riding /.ıidın/ } \rightarrow \\
\text { [..iddən] }\end{array}$ & $\begin{array}{l}\text { Children } \\
(10 ; 0- \\
17 ; 0) \text { and } \\
\text { adults }\end{array}$ & $\begin{array}{l}\text { Sydney } \\
\text { area }\end{array}$ & $\begin{array}{l}\text { Eagleson } \\
(1982)\end{array}$ & $\begin{array}{l}\text { Kaldor and } \\
\text { Malcolm } \\
(1991), \\
\text { Williams } \\
(2000)\end{array}$ \\
\hline $\begin{array}{l}/ \mathrm{y} / \text { substituted by } \\
{[\mathrm{nk}]^{a}}\end{array}$ & $\begin{array}{l}\text { Velar nasal replaced by } \\
\text { homorganic nasal- } \\
\text { plosive cluster } \\
\text { (Williams, 2000) }\end{array}$ & $\begin{array}{l}\text { something } / \mathrm{s} \Lambda \mathrm{m} \theta \mathrm{In} / \\
\rightarrow[\mathrm{s} \Lambda \mathrm{m} \theta \mathrm{In} \mathrm{k}]\end{array}$ & $\begin{array}{l}\text { Children } \\
(10 ; 0- \\
17 ; 0) \text { and } \\
\text { adults }\end{array}$ & $\begin{array}{l}\text { Sydney } \\
\text { area }\end{array}$ & $\begin{array}{l}\text { Eagleson } \\
(1982)\end{array}$ & $\begin{array}{l}\text { Kaldor and } \\
\text { Malcolm } \\
(1991), \\
\text { Williams } \\
(2000)\end{array}$ \\
\hline \multirow[t]{2}{*}{ Initial $/ \mathrm{h} /$ insertion $^{a}$} & \multirow[t]{2}{*}{$\begin{array}{l}/ \mathrm{h} / \text { insertion before an } \\
\text { initial vowel } \\
\text { (Williams, 2000) }\end{array}$} & \multirow[t]{2}{*}{$\begin{array}{l}\text { uncle / } \mathrm{plkəl} / \rightarrow \\
{[\mathrm{h} \Lambda \mathrm{yk} \text { l }]}\end{array}$} & Children & $\begin{array}{l}\text { Western } \\
\text { Australia }\end{array}$ & $\begin{array}{l}\text { Kaldor } \\
\text { and } \\
\text { Malcolm } \\
(1979 ; \\
1982)\end{array}$ & $\begin{array}{l}\text { Kaldor and } \\
\text { Malcolm } \\
\text { (1991), } \\
\text { Williams } \\
\text { (2000), }\end{array}$ \\
\hline & & & $\begin{array}{l}\text { Children } \\
(10 ; 0- \\
17 ; 0) \text { and } \\
\text { adults }\end{array}$ & $\begin{array}{l}\text { Sydney } \\
\text { area }\end{array}$ & $\begin{array}{l}\text { Eagleson } \\
(1982)\end{array}$ & $\begin{array}{l}\text { Butcher } \\
(2008)\end{array}$ \\
\hline \multirow[t]{2}{*}{ Initial $/ \mathrm{h} /$ deletion $^{a}$} & \multirow[t]{2}{*}{$/ \mathrm{h} /$ deletion } & \multirow[t]{2}{*}{$\begin{array}{l}\text { hospital /hospətəl/ } \\
\rightarrow \text { [nspətəl] }\end{array}$} & Children & $\begin{array}{l}\text { Western } \\
\text { Australia }\end{array}$ & $\begin{array}{l}\text { Kaldor } \\
\text { and } \\
\text { Malcolm } \\
(1979 ; \\
1982)\end{array}$ & $\begin{array}{l}\text { Kaldor and } \\
\text { Malcolm } \\
(1991), \\
\text { Williams } \\
\text { (2000), }\end{array}$ \\
\hline & & & Children & $\begin{array}{l}\text { Alice } \\
\text { Springs }\end{array}$ & $\begin{array}{l}\text { Sharpe } \\
(1977)\end{array}$ & $\begin{array}{l}\text { Butcher } \\
(2008)\end{array}$ \\
\hline$/ \mathrm{n} /$ deletion $^{a}$ & $\begin{array}{l}/ \mathrm{n} / \text { deleted in 'an' } \\
\text { before a vowel } \\
\text { (Williams, 2000) }\end{array}$ & an eel $\rightarrow$ a eel & $\begin{array}{l}\text { Children } \\
(10 ; 0- \\
17 ; 0) \text { and } \\
\text { adults }\end{array}$ & $\begin{array}{l}\text { Sydney } \\
\text { area }\end{array}$ & $\begin{array}{l}\text { Eagleson } \\
(1982)\end{array}$ & $\begin{array}{l}\text { Kaldor and } \\
\text { Malcolm } \\
\text { (1991), } \\
\text { Williams } \\
\text { (2000) }\end{array}$ \\
\hline $\begin{array}{l}\text { Alternation of } \\
\text { voiced and voiceless } \\
\text { plosives (context- } \\
\text { sensitive voicing) }\end{array}$ & $\begin{array}{l}\text { Alternation of voiced } \\
\text { and voiceless plosives, } \\
\text { particularly in nasal- } \\
\text { plosive clusters } \\
\text { (Williams, 2000) }\end{array}$ & $\begin{array}{l}\text { hunting /hıntın/ } \rightarrow \\
\text { [hındın] }\end{array}$ & Children & $\begin{array}{l}\text { Western } \\
\text { Australia }\end{array}$ & $\begin{array}{l}\text { Kaldor } \\
\text { and } \\
\text { Malcolm } \\
(1979 ; \\
1982)\end{array}$ & $\begin{array}{l}\text { Kaldor and } \\
\text { Malcolm } \\
\text { (1991), } \\
\text { Williams } \\
\text { (2000), } \\
\text { Butcher } \\
\text { (2008) }\end{array}$ \\
\hline
\end{tabular}


Appendix 1: (Continued)

\begin{tabular}{|c|c|c|c|c|c|c|}
\hline $\begin{array}{l}\text { Aboriginal English } \\
\text { phonological feature } \\
\text { (phonological } \\
\text { pattern) }\end{array}$ & Description & Example & Sample & Location & $\begin{array}{l}\text { Primary } \\
\text { source }\end{array}$ & $\begin{array}{l}\text { Secondary } \\
\text { source }\end{array}$ \\
\hline $\begin{array}{l}/ \mathrm{t} / \text { and } / \mathrm{d} / \\
\text { alternation with } \\
\text { flapped / } /\end{array}$ & $\begin{array}{l}\text { Alternation of alveolar } \\
\text { stops with flapped /r/ } \\
\text { (Williams, 2000) }\end{array}$ & put it $\rightarrow$ purit & Children & $\begin{array}{l}\text { Western } \\
\text { Australia }\end{array}$ & $\begin{array}{l}\text { Kaldor } \\
\text { and } \\
\text { Malcolm } \\
(1979 ; \\
1982)\end{array}$ & $\begin{array}{l}\text { Kaldor and } \\
\text { Malcolm } \\
\text { (1991), } \\
\text { Williams } \\
(2000)\end{array}$ \\
\hline $\begin{array}{l}\text { Affricatives and } \\
\text { fricatives } \\
\text { alternating with } \\
\text { palatals (later } \\
\text { stopping) }\end{array}$ & $\begin{array}{l}/ \mathrm{t} / \rightarrow[\mathrm{ts}] \\
/ \mathrm{tg} / \rightarrow[\mathrm{tj}] \\
/ \mathrm{d} / \rightarrow[\mathrm{dj}] \\
/ \mathrm{s} / \rightarrow[\mathrm{t}] \\
/ \mathrm{t} / \rightarrow[\mathrm{t}]\end{array}$ & $\begin{array}{l}\text { chicken } / \mathrm{t} \text { Ikən/ } \rightarrow \\
\text { [tjıkən] } \\
\text { scratch /skıæt / } \rightarrow \\
\text { [sk.ıæt] }\end{array}$ & Children & $\begin{array}{l}\text { Western } \\
\text { Australia }\end{array}$ & $\begin{array}{l}\text { Kaldor } \\
\text { and } \\
\text { Malcolm } \\
(1979 ; \\
1982)\end{array}$ & $\begin{array}{l}\text { Kaldor and } \\
\text { Malcolm } \\
\text { (1991), } \\
\text { Williams } \\
(2000)\end{array}$ \\
\hline \multirow[t]{2}{*}{$\begin{array}{l}\text { Fricatives } \\
\text { substituted by } \\
\text { stops: voiced and } \\
\text { voiceless (early } \\
\text { stopping) }\end{array}$} & $\begin{array}{l}/ \mathrm{v} / \rightarrow[\mathrm{b}] \\
/ \mathrm{v} / \rightarrow[\mathrm{p}] \\
/ \mathrm{f} / \rightarrow[\mathrm{p}] \\
/ \mathrm{d} / \rightarrow[\mathrm{d}] \\
/ \theta / \rightarrow[\mathrm{t}]\end{array}$ & $\begin{array}{l}/ \text { IEIS/ } \rightarrow \text { [IEIt }] \\
\text { five } / \text { faIv/ } \rightarrow \text { [paib] }\end{array}$ & Children & $\begin{array}{l}\text { Western } \\
\text { Australia }\end{array}$ & $\begin{array}{l}\text { Kaldor } \\
\text { and } \\
\text { Malcolm } \\
(1979 ; \\
1982)\end{array}$ & $\begin{array}{l}\text { Kaldor and } \\
\text { Malcolm } \\
\text { (1991), } \\
\text { Williams } \\
\text { (2000), }\end{array}$ \\
\hline & & have /hæv/ $\rightarrow$ [hæp] & Children & $\begin{array}{l}\text { Alice } \\
\text { Springs }\end{array}$ & $\begin{array}{l}\text { Sharpe } \\
(1977)\end{array}$ & $\begin{array}{l}\text { Butcher } \\
(2008)\end{array}$ \\
\hline $\begin{array}{l}\text { Affricates } \\
\text { substituted by } \\
\text { fricatives } \\
\text { (deaffrication) }\end{array}$ & & $/ \mathrm{t} \Lambda \mathrm{k} / \rightarrow\left[\int \Lambda \mathrm{k}\right]$ & Children & $\begin{array}{l}\text { Western } \\
\text { Australia }\end{array}$ & $\begin{array}{l}\text { Kaldor } \\
\text { and } \\
\text { Malcolm } \\
(1979)\end{array}$ & \\
\hline $\begin{array}{l}\text { Alternation of } \\
\text { alveolar and palatal } \\
\text { fricatives }\end{array}$ & $/ \mathrm{s} / / \mathrm{J} / / \mathrm{z} / / 3 /$ alternation & $\begin{array}{l}/ \mathrm{fI} \int / \rightarrow[\mathrm{fis}] \\
/ \mathrm{boIz} / \rightarrow[\mathrm{boIs}]\end{array}$ & Children & $\begin{array}{l}\text { Western } \\
\text { Australia }\end{array}$ & $\begin{array}{l}\text { Kaldor } \\
\text { and } \\
\text { Malcolm } \\
(1979 ; \\
1982)\end{array}$ & $\begin{array}{l}\text { Kaldor and } \\
\text { Malcolm } \\
\text { (1991), } \\
\text { Williams } \\
(2000)\end{array}$ \\
\hline $\begin{array}{l}\text { Diphthongs } \\
\text { alternating with } \\
\text { short clear vowels }^{a}\end{array}$ & & $/ \mathrm{hpum} / \rightarrow[\mathrm{hpm}]$ & Children & $\begin{array}{l}\text { Western } \\
\text { Australia }\end{array}$ & $\begin{array}{l}\text { Kaldor } \\
\text { and } \\
\text { Malcolm } \\
(1979 ; \\
1982)\end{array}$ & $\begin{array}{l}\text { Kaldor and } \\
\text { Malcolm } \\
(1991), \\
\text { Williams } \\
(2000)\end{array}$ \\
\hline \multirow[t]{2}{*}{$\begin{array}{l}\text { Reduction in } \\
\text { consonant clusters, } \\
\text { particularly in word } \\
\text { final position } \\
\text { (cluster reduction) }\end{array}$} & & $\begin{array}{l}\text { biggest /bigəst/ } \rightarrow \\
\text { [bigəs] }\end{array}$ & Children & $\begin{array}{l}\text { Western } \\
\text { Australia }\end{array}$ & $\begin{array}{l}\text { Kaldor } \\
\text { and } \\
\text { Malcolm } \\
(1979 ; \\
1982)\end{array}$ & $\begin{array}{l}\text { Williams } \\
(2000)\end{array}$ \\
\hline & & $\begin{array}{l}\text { mister } / \text { mistə/ } \rightarrow \\
{[\operatorname{mit} \Lambda]}\end{array}$ & Children & $\begin{array}{l}\text { Alice } \\
\text { Springs }\end{array}$ & $\begin{array}{l}\text { Sharpe } \\
\text { (1977) }\end{array}$ & \\
\hline $\begin{array}{l}\text { Clear (non- } \\
\text { velarised) } / 1 / \text { in post- } \\
\text { vocalic position }{ }^{a}\end{array}$ & & well /wet/ $\rightarrow$ [wel] & - & - & - & $\begin{array}{l}\text { Butcher } \\
(2008)\end{array}$ \\
\hline $\begin{array}{l}\text { Insertion of /a/ } \\
\text { (epenthesis) }\end{array}$ & & $\begin{array}{l}\text { sleeping /slipıy/ } \rightarrow \\
\text { [solipın] }\end{array}$ & Children & $\begin{array}{l}\text { Alice } \\
\text { Springs }\end{array}$ & $\begin{array}{l}\text { Sharpe } \\
(1977)\end{array}$ & $\begin{array}{l}\text { Butcher } \\
(2008)\end{array}$ \\
\hline
\end{tabular}


Appendix 1: (Continued)

\begin{tabular}{|c|c|c|c|c|c|c|}
\hline $\begin{array}{l}\text { Aboriginal English } \\
\text { phonological feature } \\
\text { (phonological } \\
\text { pattern) }\end{array}$ & Description & Example & Sample & Location & $\begin{array}{l}\text { Primary } \\
\text { source }\end{array}$ & $\begin{array}{l}\text { Secondary } \\
\text { source }\end{array}$ \\
\hline $\begin{array}{l}\text { Fronting and raising } \\
\text { of vowels in the } \\
\text { presence of palatal } \\
\text { consonants }^{a}\end{array}$ & & catch $/ \mathrm{kæt} / \rightarrow[\mathrm{kct}]$ & - & - & - & $\begin{array}{l}\text { Butcher } \\
(2008)\end{array}$ \\
\hline $\begin{array}{l}\text { Primary stress on } \\
\text { first syllable }{ }^{a}\end{array}$ & & $\begin{array}{l}\text { police /pəlis/ } \rightarrow \\
\text { [plis] } \\
\text { kangaroo /kængə.ıu/ } \\
\rightarrow \text { [kæyg.ıu] }\end{array}$ & Children & $\begin{array}{l}\text { Western } \\
\text { Australia }\end{array}$ & $\begin{array}{l}\text { Kaldor } \\
\text { and } \\
\text { Malcolm } \\
(1979 ; \\
1982)\end{array}$ & $\begin{array}{l}\text { Kaldor and } \\
\text { Malcolm } \\
(1991), \\
\text { Butcher } \\
(2008)\end{array}$ \\
\hline
\end{tabular}

Note: ${ }^{a}$ This feature of Aboriginal English does not have an equivalent phonological pattern.

Disclaimer: An assumption was made about AAE being standard across Australia; however, it cannot be, due to the diversity of Indigenous languages and culture. Unfortunately, there is no current data providing insights into this area. Therefore, due to the lack of data, all variations found within the literature to date have been included. We acknowledge that the numerous Indigenous languages found throughout Australia will not produce a uniform language.

\section{Appendix 2: Australian Aboriginal English (AAE) transcriptions of words from the Diagnostic Evaluation of Articulation and Phonology (DEAP, Dodd et al. 2002)}

\begin{tabular}{|c|c|c|c|}
\hline \multirow{2}{*}{$\begin{array}{l}\text { DEAP } \\
\text { target word }\end{array}$} & \multirow{2}{*}{$\begin{array}{l}\text { DEAP } \\
\text { transcription }\end{array}$} & \multicolumn{2}{|r|}{$\mathrm{AAE}_{\text {variations }}{ }^{a}$} \\
\hline & & Transcription & Definition (phonological pattern) \\
\hline \multirow[t]{2}{*}{ Teeth } & [tie] & [tif] & $\begin{array}{l}\text { Interdental fricatives replaced by labio-dental fricatives (fricative } \\
\text { simplification) }\end{array}$ \\
\hline & & [tit] & Fricatives alternating with stops - voiced or voiceless \\
\hline \multirow[t]{2}{*}{ This } & [ðıs] & [dis] & Fricatives alternating with stops (voiced or voiceless) \\
\hline & & [vis] & $\begin{array}{l}\text { Interdental fricatives replaced by labio-dental fricatives (fricative } \\
\text { simplification) }\end{array}$ \\
\hline \multirow[t]{3}{*}{ House } & [haus] & [aus] & Initial $/ \mathrm{h} /$ deletion \\
\hline & & {$[\mathrm{h} \Lambda \mathrm{s}]$} & Diphthongs alternating with short clear vowels \\
\hline & & [haut] & Affricatives and fricatives alternating with palatals \\
\hline \multirow[t]{3}{*}{ Egg } & {$[\varepsilon g]$} & [eıg] & Diphthongs alternating with short clear vowels \\
\hline & & [heg] & $/ \mathrm{h} /$ insertion before an initial vowel \\
\hline & & [عk] & Alternation of voiced and voiceless plosives (context-sensitive voicing) \\
\hline \multirow[t]{3}{*}{ Pram } & [pıæm] & [pæm] & Cluster reduction \\
\hline & & [p.ıəm] & Diphthongs alternating with short clear vowels \\
\hline & & {$[\mathrm{b} . æ m]$} & $\begin{array}{l}\text { Alternation of voiced and voiceless plosives (context-sensitive voicing); } \\
\text { reduction in consonant clusters }\end{array}$ \\
\hline
\end{tabular}

Note: ${ }^{a}$ Variations were informed from the sources described in Appendix 1. 